\title{
Information ethics in the perspective of the knowledge-based economy
}

Keywords: knowledge-based economy, information ethics, information services

Słowa kluczowe: gospodarka oparta na wiedzy, etyka informacji, usługi informacyjne

\section{Introduction}

The revolution in information and communication technologies (ICTs) has implied the revaluation of the classical paradigm of the industrial economy towards knowledgebased economy (KBE), where the informational mode, in which information processing together with knowledge generation and diffusion by means of multimodal, flexible, and networked communication, is the main source of productivity and competitive advantage (Castells, 2013). However, both the economic development correlative and the social transformation towards the information society (IS) create the new prerequisites for the workforce and result in the changes of the social stratification model. Simultaneously, information is seen frequently as the most valuable asset providing a competitive advantage and its acquisition, retrieval and distribution can inflict some ethical challenges to be faced.

The reflections on the topic of this paper are focused on ethical dilemmas interdependent on information generation, acquisition and processing in the $\mathrm{KBE}$ environment. The article begins with a brief description of the ethical implications the $\mathrm{KBE}$ brings in socio-economic terms, including a shift in the social stratification system. Subsequently, the KBE's SWOT analysis in the moral perspective is presented.

\footnotetext{
* mgr Anna Waligórska-Kotfas, Państwowa Wyższa Szkoła Zawodowa w Koninie, Katedra Finansów i Logistyki, anna.kotfas@konin.edu.pl
} 
Furthermore, information ethics is outlined, both in the micro and macro approach. Finally, some deontological obligations of the information professionals who are recognized as the KBE beneficiaries are discussed. In conclusion, the information professionals' responsibility towards society in the KBE realms is underlined. The paper is based on English and Polish literature studies and research, available both in print and online, concerning the KBE, information ethics and the codes of professional conduct.

\section{The Promise and Peril of the KBE}

The KBE is a set of interrelated production and consumption activities determined by: digitalization and virtualization of the processes; flexibility, decentralization and integration, both in micro and macro level; innovation and creativity, also in terms of prosumption; immediacy due to the global and multimodal communication (Castells, 2003, 2013; Comor, 2010). The vital factor of the KBE is the combination of the ICTs application and the reliance on intellectual and mental capabilities of the workforce, which in turn implies a transition in economic and social relationships.

In the realms of KBE, the key aspect is human capital and its competence. M. Castells (2003, pp. 106-107) states that

the e-economy cannot function without workers able to navigate, both technically and in terms of content, this deep sea of information, organizing it, focusing it, and transforming it into specific knowledge, appropriate for the task and purpose of the work process.

Digital wisdom, defined as being informed, inspired and supported by digital enhancements (Prensky, 2009), becomes the crucial feature of homo sapiens digital. The workforce that is self-programmable, creative, adaptable, mobile and able to manage constant uncertainty is to substitute generic (manual) workers with no particular abilities or qualifications, who in turn become redundant and will eventually be replaced by robots (Castells, 2013). Simultaneously, since the content of labor becomes mental, the productivity becomes imprecise as the ratio of time to quantity of value produced is difficult to establish. Additionally, the work which is dependent on the information and knowledge elaboration tends to be highly specialized and non-transferable, although from the ergonomic point of view it appears indistinguishable. As a consequence, digital labor is considered to be particularly personalized and per se becomes the foremost and singularized part of the worker's life (Berardi, 2005).

The KBE's informational paradigm together with the workforce prerequisites translate into the transformation of the social stratification system in the IS, in which the following social classes are highlighted: lumpenproletariat (TV watchers, computer- 
game players, passive ICTs users); cognitariat (active and conscious ICTs users, yet not able to alter, let alone create, the content); digitariat (fluent ICTs users constructing the information systems and processing information in order to develop knowledge). ${ }^{1}$ The contemporary social divide is embedded in meritocracy together with information literacy and digital skills (Castells, 2013; Dijk, 2005, Fiut, Habryń, 2001; Jemielniak 2012; Webster, 2014).

Table 1. The SWOT analysis of the KBE's aspects in the ethical perspective

\begin{tabular}{|c|c|}
\hline KBE & Description \\
\hline 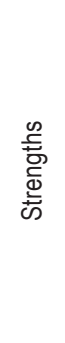 & $\begin{array}{l}\text { - Increases opportunities for the individual development and the disclosure of the talents and the interests } \\
\text { of individuals. } \\
\text { - Createsamore enlightened and rational society. } \\
\text { - Dynamizesthe economic andcivilization growth, which brings positive consequences in terms of reduced } \\
\text { poverty and pathology. } \\
\text { - Generates an increase in innovation and leads to the new products and services, including the intangible ones, } \\
\text { which can servethe spiritual development of a human being. } \\
\text { - Allows better understandingand thorough use of the civilization achievements, which in turn positively influence } \\
\text { the quality of life and ethical attitudes. }\end{array}$ \\
\hline 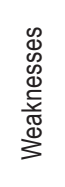 & $\begin{array}{l}\text { - Requires significant investments in education, science, R\&D, and the related infrastructure, which can be } \\
\text { difficult to finance inpoorer societies and can happen at the expense of meeting other social needs. } \\
\text { - Is attractive to that part ofsociety that has more intellectual and creative potential, excluding those with fewer } \\
\text { opportunities and abilities in this regard. } \\
\text { - Reinforces existing social segmentation between white collars and red necks. }\end{array}$ \\
\hline 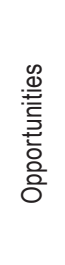 & $\begin{array}{l}\text { - Increases the level of social sensitivity and knowledge by providing the wider access to information } \\
\text { and communication. } \\
\text { - Can protect the society against dictatorship and oppression by reclaiming the electorate from the populist, } \\
\text { demagogic politicians. } \\
\text { - Allowsthe effective opposition to various pathologies, which were previously tolerated or considered to be } \\
\text { impossible to eradicate (bullying, nepotism, corruption). } \\
\text { - Gives a chance of accelerated civilizational advance forthe laggard countries and regions. }\end{array}$ \\
\hline 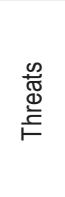 & $\begin{array}{l}\text { - May imply the emergence of the new extremities of wealth and poverty. } \\
\text { - Can determine the dichotomous division of the society into winners and losers. } \\
\text { - May unwittingly create winners' pride and arrogance, their disregard and contempt for people who are less } \\
\text { educated, less resourceful and lost in the new surroundings. } \\
\text { - May result in a negative job balance. }\end{array}$ \\
\hline
\end{tabular}

Source: own elaboration based on Kietliński (2009).

The KBE's SWOT analysis with regard to its ethical dimensions was conducted by K. Kietliński between 2008 and 2009. The research sample of 316 respondents was selected by a purposive sampling method and the results obtained from the conducted survey were scrutinized by implementing a factor analysis together with the Kendall

1 The literature discourse is not consistent in defining terms cognitariat and ditigariatand; they are interchanged (Materska, 2007; Sienkiewicz, Nowak, 2008). 
rank correlation coefficient and the Pearson product-moment correlation coefficient. The findings of the study positively verified the following hypothesis: although the KBE brings both the promise and peril, in the ethical perspective the advantages outweigh the disadvantages (Kietliński, 2009).

His study K. Kietliński (2009, p. 268) summarizes by stating:

A human being is (...) the cause and the purpose of all creative activity. Claiming his predominant role in the economic processes requires the recognition of freedom, dignity, and a certain moral order as the factors constituting the process of production, exchange, division and dissemination of all goods, including products of the KBE, which therefore should always serve the genuine good.

Nonetheless, the awareness of the potential and authentic KBE's weaknesses and threats should be food for thought in terms of the workforce stratification, the social exclusion, and the digital divide.

\section{The Information Ethics and its Micro and Macro Conceptualization}

At the end of the $20^{\text {th }}$ century information ethics (IE) evolved from that of traditionally identified with library activities to the issues correlated with media, cyberspace, bio-information, cybernetics, ICTs business. The common point of this interdisciplinary discourse is the contemporary concern over free access to information, freedom of speech and respect for the principles of democracy while preserving the right to privacy and copyright together with security, confidentiality and integrity of services provided in global, multimodal and virtual environment.

Among the IE research areas, there are three fields of ethical dilemmas corresponding to the production of information, its classification and finally the access and dissemination of information (ICIE, 2015). Effortless information multiplication in the digital age implies the ethical issues associated with finding a balance between the concept of copyright protection and the concept of universal access to information and the possibility of its recombination. Yet another matter lies in personal data protection in the face of mass-scale information sharing in social networks. Ethical questions regarding the information classification can be reduced to information control and censorship. This applies equally to the traditional classification systems as well as search engines intentionally or unintentionally selecting and proceeding the search results (Sherman, Price, 2001). The third aspect of the IE pertains to the access to information and its dissemination. Information as a product has an economic value that should be protected. Ethical problems here are interrelated to keeping the balance between the universal 
human right to information and communication and the issue of confidentiality, the access to strategic information and its unauthorized disclosure or misinformation, particularly in view of Big Data analysis (Waligórska-Kotfas, 2015).

The micro perspective of IE considers information as:

- a resource (input) - moral issues arising from the triple A: availability, accessibility, accuracy of informational resources, independently of their format and physical representation; additionally, from the information consumer's point of view the questions concerning reliability, trustworthiness and relevance of information sources need to be raised here,

- a product (output) - ethical problems regarding pragmatic rules of communication such as: accountability, liability, libel, plagiarism, advertising, propaganda, misinformation,

- a target (environment) - the dilemmas over information security, its vandalism, piracy and hacking, intellectual property rights, freedom of expression and censorship, filtering and contents control; the social dimension includes the digital divide and the ICTs illiteracy (Floridi, 2006).

The IE model in the macro scale combines the elements given above with the overall information cycle including the information creation, elaboration, storage, protection, usage, and distribution to analyze the actions and interactions of informational entities within the info-environment. According to L. Floridi (2006, p. 32) IE determines what is morally right or wrong by means of four basic moral laws:

- entropy ought not to be caused in the infosphere (null law),

- entropy ought to be prevented in the infosphere,

- entropy ought to be removed from the infosphere,

- the flourishing of informational entities as well as of the whole infosphere ought to be promoted by preserving, cultivating and enriching their properties.

The ethical agent in the ICTs era is homo poieticus, who is a demiurge, an active constructor of the info-world, improving its nature and shaping its development, performing creative stewardship, generating info-artefacts and knowledge, together with creating concepts (Floridi, Sanders, 2003; Russo, 2012).

Generalizing, the contemporary IE focuses on various aspects of communication via the ICTs and attempts to adjust the general moral standards to the specific conditions created by digital, multimodal e-nvironment.

\section{Deontological Obligations for Information Professionals in the KBE Conditions}

The occupations interrelated with information have always been present within the society and the labor market. However, the KBE emergence adds some new 
professions (an information architect, an information broker, a knowledge management specialist, a webpage content manager) to the ones traditionally associated with information and its processing (a librarian, an information scientist). Simultaneously, the professional conduct corresponding the obligations towards the IE is equally required.

Theoretical issues discussed above in practice oblige an information professional to: the precise delineation of the information needs; the thorough assessment of information sources on account of their legality, transparency, accessibility, accuracy, relevance and validity; the verification of the obtained information to the level of detail, timeliness, reliability, usability and compatibility with respect to the information needs; the diligence and objectivity in the information selection and processing, which excludes manipulation, disinformation, contingency, and personal partiality. An information professional must be aware that information, particularly economic and business information, which is ambiguous, unsubstantiated, incorrect, incomplete, distorted or manipulated, results in inaccurate strategic decisions affecting the competitive advantage or the financial position.

In the era of globalization and liberalization the straightforward formulation of deontological standards of a profession is a priority. The professional code, regarded as a systematized, consistent, and applicable guideline to mediating the conflicts that can occur both between the individuals, as well as the professionals as a group and the society, can be a significant support in overcoming morally vague circumstances (Martin, 2000).

Code of Ethical Business Practice, Code of Ethics for CI Professionals, and IFLA Code of Ethics for Librarians and other Information Workers (AIIP, 2015; IFLA, 2015, SCIP, 2015) exemplify the concise and declarative code of conduct for information professionals and define the following accountability points: the IE issues in terms of information as a resource, a product and a target in the e-nvironment; the necessity of the compliance with the legal regulations including intellectual property rights; the concern regarding privacy, confidentiality, honesty, competence and impartiality; the constant work for the information literacy promotion and the digital divide elimination; the continuous strive to uphold the highest standards of the profession leading to its recognition and respect. Unfortunately, apart from Librarians Profession Code of Ethics (PLA, 2005), there is no attempt to codify and guide Polish information professionals when facing the professional and ethical dilemmas in the digital era.

\section{Conclusion}

The present paradigm shift towards the KBE results in multi-faceted socio-economic transformations that lead to ethical considerations. Creating knowledge fosters innovation and dynamic economic growth and contributes to the progress of civilization. 
Concurrently, it might condition the new social stratification based on either technology or intellectual exclusion and might be a menace in socio-ethical terms.

The KBE depends on information since the multimodal, networked, free and global access to information, together with its acquisition, processing, retrieval and distribution, enhance the diffusion of knowledge. Parallelly, it contributes to information overload and chaos, lack of personal data protection, the violation of intellectual property rights, and the disclosure of strategically valuable information. As a result the ethical dilemmas correlated with handling information in the morally right manner appear.

The conclusion conducts to the thought that an information professional in the KBE environment might be recognized as a personification of homo poieticus given that they arrange, unscramble and shape infosphere by sorting out the e-nvironment according to the users' informational needs. Additionally, their conduct in accordance with deontological obligations of the profession contributes to the information entropy decline. However, as the KBE beneficiary associated with digitariat, an information professional should be aware of their privileged position and remember about their obligations towards society in terms of preventing the social and digital divide.

\section{References}

AIIP (2015). Code of Ethical Business Practice. Retrieved from: http://www.aiip.org/About/ Code-of-Ethical-Business-Practice (1.10.2015).

Berardi, F. (2005). What Does Cognitariat Mean? Work, Desire, Depression. Cultural Studies Review, 11 (2), 57-63. DOI: http://dx.doi.org/10.5130/csr.v11i2.3656.

Castells, M. (2003). Galaktyka Internetu: refleksje nad Internetem, biznesem i społeczeństwem. Poznań: Rebis.

Castells, M. (2013). Społeczeństwo sieci. Warszawa: Wydawnictwo Naukowe PWN.

Comor, E. (2010). Digital prosumption and alienation. Ephemera: Theory \& Politics in Organization, 10 (3/4), 439-454.

Dijk, J.A.G.M. van. (2005). The Deepening Divide: Inequality in the Information Society. Thousand Oaks: Sage.

Fiut, I., Habryń, M. (2001). Społeczność akademicka wobec możliwości wykorzystania Internetu w procesie pracy. In: L.H. Haber (ed.), Mikrospołeczność informacyjna na przykładzie miasteczka internetowego Akademii Górniczo-Hutniczej w Krakowie (pp. 127-164). Kraków: Uczelniane Wydawnictwa Naukowo-Dydaktyczne AGH.

Floridi, L. (2006). Information Ethics, its Nature and Scope. SIGCAS Computers and Society, 36 (3), 21-36.

Floridi, L., Sanders, J.W. (2003). Internet Ethics: the Constructionist Values of Homo Poieticus. In: R.J. Cavalier (ed.), The Impact of the Internet on Our Moral Lives (pp. 195-214). New York: State University of New York.

ICIE (2015). International Centre for Information Ethics. Retrieved from: http://icie.zkm.de/ research (22.11.2015).

IFLA (2015). IFLA Code of Ethics for Librarians and other Information Workers. Retrieved from: http://www.ifla.org/news/ifla-code-of-ethics-for-librarians-and-other-informationworkers-full-version (5.12.2015). 
Jemielniak, D. (2012). The New Knowledge Workers. Cheltenham: Edward Elgar Publishing.

Kietliński, K. (2009). Moralność gospodarki opartej na wiedzy. Warszawa: Wydawnictwo Uniwersytetu Kardynała Stefana Wyszyńskiego.

Martin, M.W. (2000). Meaningful Work: Rethinking Professional Ethics. New York: Oxford University Press.

Materska, K. (2007). Informacja w organizacjach wiedzy. Warszawa: Wydawnictwo SBP.

PLA (2005). Librarians Profession Code of Ethics (Kodeks Etyki Bibliotekarza i Pracownika Informacji). Retrieved from: http://www.sbp.pl/dla_bibliotekarzy/przepisy_prawne/ kodeks_etyki_bibliotekarza (29.11.2015).

Prensky, M. (2009). Homo Sapiens Digital: From Digital Immigrants and Digital Natives to Digital Wisdom. Innovate: Journal of Online Education, 5 (3). Retrieved from:http://nsu works.nova.edu/innovate/vol5/iss3/1 (22.11.2015).

Russo, F. (2012). The homo poieticus and the bridge between physis and techne. In: H. Demir (ed.), Luciano Floridi's Philosophy of Technology (p. 65-81). Dordrecht: Springer Science. DOI: 10.1007/978-94-007-4292-5_4.

SCIP (2015). Code of Ethics for CI Professionals. Retrieved from: https://www.scip.org/ CodeOfEthics.php (29.11.2015).

Sherman, Ch., Price, G. (2001). The Invisible Web: Uncovering Sources Search Engines Can't See. Medford: Information Today Inc.

Sienkiewicz, P., Nowak, J.S. (ed.) (2008). Społeczeństwo informacyjne: krok w przód, dwa kroki w tyt. Katowice: Polskie Towarzystwo Informatyczne - Oddział Górnośląski.

Waligórska-Kotfas, A. (2015). Big Data: implikacje etyczne gromadzenia i przetwarzania informacji w organizacjach. Prace Naukowe Wyższej Szkoły Bankowej w Gdańsku, 40, $181-194$.

Webster, F. (2014). Theories of the Information Society. New York: Routledge.

\section{Abstract}

The transformation of the modern economy paradigm towards the knowledge-based economy (KBE) has led to the creation and expansion of new products and services. Simultaneously, the socio-economic shift interdependent on the information processing and knowledge diffusion results in ethical dilemmas. The reflections on the topic of this paper are firstly focused on the SWOT analysis of the socio-economic issues corresponding with the emergence of the $\mathrm{KBE}$. Furthermore, information ethics in macro as well as micro perspectives discussed. Finally, some ethical responsibilities of the KBE's beneficiaries are considered.

\section{Etyka informacji w gospodarce opartej na wiedzy}

Implikowana przemianami w zakresie technologii informacyjno-komunikacyjnych transformacja paradygmatu współczesnej gospodarki w kierunku gospodarki opartej na wiedzy indukuje kreatywność i innowacyjność w tworzeniu i ekspansji nowych produktów i usług. Jednocześnie zachodzące zmiany społeczno-ekonomiczne związane z generowaniem, przetwarzaniem i wykorzystaniem wiedzy bazującej na informacji prowadzą do refleksji natury etycznej. W pierwszej części artykułu dokonano analizy SWOT gospodarki opartej na wiedzy oraz nakreślono zagadnienia etyczne z nią współzależne. Następnie przedyskutowano kwestie etyki informacji na poziomie mikro i makro. Ostatnia część publikacji koncentruje się na deontologicznych powinnościach beneficjentów gospodarki opartej na wiedzy. 